\title{
Reactivation of Bentgrass Dead Spot and Growth, Pseudothecia Production, and Ascospore Germination of Ophiosphaerella agrostis
}

\author{
J. E. Kaminski and P. H. Dernoeden, Department of Natural Resource Sciences and Landscape Architecture, Uni- \\ versity of Maryland, College Park 20742; N. R. O'Neill, USDA-ARS, Beltsville, MD 20705; and B. Momen, De- \\ partment of Natural Resource Sciences and Landscape Architecture, University of Maryland, College Park 20742
}

\begin{abstract}
Kaminski, J. E., Dernoeden, P. H., O’Neill, N. R., and Momen, B. 2002. Reactivation of bentgrass dead spot and growth, pseudothecia production, and ascospore germination of Ophiosphaerella agrostis. Plant Dis. 86:1290-1296.

Ophiosphaerella agrostis incites bentgrass dead spot (BDS) of creeping bentgrass. Little is known about the biology of $O$. agrostis; hence the primary goal of this study was to determine some basic biological properties of the pathogen and epidemiological components of the disease. Winter-dormant creeping bentgrass field samples showing symptoms of BDS were incubated at temperatures ranging from 15 to $30^{\circ} \mathrm{C}$. Between 12 and 28 days of incubation, reactivation of BDS symptoms occurred at temperatures $\geq 20^{\circ} \mathrm{C}$, but the greatest expansion in BDS patch diameter occurred at 25 and $30^{\circ} \mathrm{C}$. The optimum temperatures for growth of hyphae among $10 \mathrm{O}$. agrostis isolates ranged from 25 to $30^{\circ} \mathrm{C}$, and growth was suppressed at $35^{\circ} \mathrm{C}$. Pseudothecia of $O$. agrostis were produced in vitro on a mixture of tall fescue seed and wheat bran. Pseudothecia developed under constant fluorescent light at 13 to $28^{\circ} \mathrm{C}$, but no pseudothecia developed in darkness at any temperature. Pseudothecia developed in as few as 4 days, but the highest numbers appeared about 30 days after incubation began. Ascospores incubated at $25^{\circ} \mathrm{C}$ germinated in as little as $2 \mathrm{~h}$, with germ tubes generally emerging from the terminal rather than interior cells of ascospores. Germination during the first $4 \mathrm{~h}$ of incubation was enhanced by both light and the presence of bentgrass leaves or roots. After $18 \mathrm{~h}$ of incubation, however, there were few differences in the percentage of ascospores germinated regardless of light treatment or presence of plant tissue.
\end{abstract}

Additional keywords: Ophiosphaerella herpotricha, O. korrae, O. narmari, turfgrass

Creeping bentgrass (Agrostis stolonifera L.) is a commonly used turfgrass species on golf course putting greens throughout the United States because of its ability to withstand low mowing heights and intense cultural practices, and because it provides a high-quality putting surface. In 1999, Dernoeden et al. (5) discovered a new disease of creeping bentgrass incited by an unidentified species of Ophiosphaerella. Through morphological and molecular studies, it was shown that the pathogen constituted a new species, Ophiosphaerella agrostis Dernoeden, M.P.S. Câmara, N.R. O’Neill, van Berkum et M.E. Palm (2). The disease was named bentgrass dead spot (BDS) (4).

On creeping bentgrass grown on golf course putting greens subjected to low mowing heights, BDS appears initially as small, reddish-brown or copper colored

Corresponding author: P. H. Dernoeden

E-mail: pd9@umail.umd.edu

Accepted for publication 3 July 2002.

Publication no. D-2002-0919-01R

(C) 2002 The American Phytopathological Society spots approximately $1.0 \mathrm{~cm}$ in diameter, which may increase to about $8.0 \mathrm{~cm}$ in diameter (5). As the disease progresses, grass in the center of the spot becomes tan, while leaves in the periphery of the spot appear reddish-brown. Patches may be distributed throughout the putting green or localized, but the spots and patches generally do not coalesce. Sometimes the spots form depressions or pits in the putting surface. Turf recovers very slowly, as stolon growth into dead patches appears restrained or inhibited. Active disease symptoms generally are not observed during the winter months; however, spots that have not fully recovered often remain visible until summer. Numerous pseudothecia can be found on necrotic leaf, sheath, and stolon tissues. Field observations suggest that BDS is a polycyclic disease and that $O$. agrostis exists solely in its sexual state (2).

Spegazzini (14) described O. graminicola Speg., the type species of the genus, which he found to be a pathogen of sprangletop (Leptochloa virgata (L.) P. Beauv.) in Argentina. Three other turfgrass pathogens within the genus Ophiosphaerella have been described. $O$. herpotricha
(Fr.:Fr.) J. Walker; O. korrae (J. Walker \& A.M. Smith) R.A. Shoemaker \& C.E. Babcock (=Leptosphaeria korrae J. Walker \& A.M. Smith); and O. narmari (J. Walker \& A.M. Smith) Wetzel, Hulbert \& Tisserat (=L. narmari J. Walker \& A.M. Smith) cause spring dead spot of bermudagrass (Cynodon dactylon (L.) Pers.) (3,8,13,16, 17,19). O. herpotricha also causes spring dead spot in buffalograss (Buchloë dactyloides (Nutt.) Engelm.) (15). Necrotic ring spot of creeping red fescue (Festuca rubra L. subsp. rubra), Kentucky bluegrass (Poa pratensis L.), and annual bluegrass (Poa annua L.) is incited by $O$. korrae $(6,10,20)$. All of the aforementioned Ophiosphaerella species, except $O$. graminicola, are turfgrass root pathogens. The three root pathogens are characterized as producing darkly pigmented hyphae on roots, but none have been reported to infect creeping bentgrass. $O$. agrostis is commonly isolated from symptomatic leaves and stems during the summer months, but hyphae seldom are observed on roots.

There is little information regarding the biology of $O$. agrostis. The goal of these studies was to elucidate some basic biological properties of the pathogen and epidemiological components of BDS. The primary objectives of this investigation were: (i) to assess reactivation of the disease from winter-dormant, field-diseased creeping bentgrass at various temperatures; (ii) to determine the cardinal (maximum, minimum, and optimum) temperatures for growth of $O$. agrostis and to describe colony morphology at each temperature; (iii) to develop a technique to produce pseudothecia and ascospores in vitro; and (iv) to evaluate factors that promote ascospore germination.

\section{MATERIALS AND METHODS}

BDS reactivation. Plugs with inactive BDS symptoms from Virginia, Pennsylvania, and Maryland were collected from golf courses and incubated at four temperatures $\left(15,20,25\right.$, and $\left.30^{\circ} \mathrm{C}\right)$ in 1999,2000 , and 2001, respectively. All diseased samples were determined to be BDS based on the presence of pseudothecia within dead spots or symptoms observed during periods of disease activity. Active disease symptoms were not observed for at least 2 
months prior to sampling. Development of reddish-brown bentgrass leaves along the periphery of dead spots and an increase in patch diameter were used to assess reactivation of the disease. Reactivation was assessed using winter-dormant samples of creeping bentgrass of 'Pennlinks' from Lowe's Island Club, Sterling, VA; cultivar blend 'L-93' + 'Providence' + 'SR 1020' from Inniscrone Country Club, Avondale, PA; and 'L-93' from the University of Maryland Turfgrass Research Facility, College Park, MD. Samples from Virginia and Maryland were collected from the putting surface, whereas those from Pennsylvania were from the higher cut collar. Turf at all three sites was grown on sandbased root-zone mixes. At Virginia, three applications of chlorothalonil (tetrachloroisophthalonitrile) and iprodione (3-(3,5dichlorophenyl)- $N$-(1-methylethyl)-2,4-dioxo1-imidazolidinecarboxamide) were made between 19 October and 15 November 1998 before samples were collected on 1 February 1999. Greens in Virginia were overseeded with 'Pennlinks' creeping bentgrass during the autumn of 1998. Turf at Pennsylvania received several applications of iprodione and thiophanate methyl (dimethyl-4-4'-o-phenylenebis-3-thioallophanate) between 2 October and 24 November 1999, prior to sampling on 28 February 2000. The turf at Maryland received applications of chlorothalonil, triadimefon (1-(4-chlorophenoxy)-3,3-dimethly-1-(1H1,2, 4-triazol-1-yl)-2-butanone), and fenarimol ( $\alpha$-(2-chlorophenyl)- $\alpha$-(4-chlorophenyl)5 -pyrimidinemethanol) between 20 October and 10 November 2000, prior to sampling on 17 January 2001.

Four 100 -mm-diameter by 50 -mm-deep plugs from each site containing small diseased spots (14 to $48 \mathrm{~mm}$ ) were watered to field capacity, sealed in plastic bags, and placed in growth chambers at each of four temperatures $\left(15,20,25\right.$, and $\left.30^{\circ} \mathrm{C}\right)$. Plugs were randomized in each growth chamber and included four replicates per temperature treatment. While only diseased plugs from Virginia were tested, an additional four plugs of symptomless creeping bentgrass were obtained from the same aforementioned golf greens in Pennsylvania and Maryland. Control plugs were incubated under the aforementioned conditions. All plugs were subjected to a 12-h photoperiod. Photosynthetically activated radiation (PAR) was measured from inside the plastic bag with a Quantum Sensor (Apogee Instruments Inc., Logan, UT). The distance between the fluorescent light source and diseased samples in the four growth chambers was adjusted to provide an average PAR of $88 \mu \mathrm{mol} \cdot \mathrm{m}^{-2} \cdot \mathrm{s}^{-1}$ (range $=77$ to 93 $\mu \mathrm{mol} \cdot \mathrm{m}^{-2} \cdot \mathrm{s}^{-1}$ ). Each year, frozen samples were acclimated on a lab bench for $24 \mathrm{~h}$ prior to incubation. It was determined prior to initiation of the experiment that diseased samples incubated at temperatures $\geq 25^{\circ} \mathrm{C}$ were prone to drying within $24 \mathrm{~h}$; therefore plugs were placed in plastic bags to prevent desiccation. Diseased samples in plastic bags received approximately $50 \mathrm{ml}$ of distilled water every 3 to 5 days as the soil began to dry. Leaves were trimmed to approximately $1 \mathrm{~cm}$ in height as needed, and plugs were monitored every 2 to 10 days for disease symptoms. Isolation of $O$. agrostis was attempted during and at the completion of each experiment.

Disease reactivation was visually assessed based on the appearance of reddishbrown or copper colored leaves at the periphery of spots. BDS reactivation was assessed by measuring patch diameter in two directions with a ruler, and mean patch diameter was used for the statistical analyses. Mean patch diameter data were analyzed on individual rating dates using the SAS MIXED procedure, and means were separated using Fisher's protected $(P \leq$ 0.05) least significant difference multiple mean comparison test.

Cardinal temperatures for growth of O. agrostis. The growth rates of 10 isolates of $O$. agrostis were compared at six temperatures $\left(10,15,20,25,30\right.$, and $\left.35^{\circ} \mathrm{C}\right)$. All isolates previously were shown to be O. agrostis by Câmara et al. (2). A $5-\mathrm{mm}-$ diameter disk of mycelia was removed from the outer edge of an actively growing colony on potato dextrose agar (PDA) and placed in the center of a petri dish containing 15 to $20 \mathrm{ml}$ of PDA. The dishes then were sealed with Parafilm and incubated in the dark. Colony diameters were measured with a ruler in two directions to obtain a mean, with measurements made every $24 \mathrm{~h}$ until mycelia of the fastest growing isolate reached the perimeter of the plate. Colony expansion for each isolate between day 2 and day 10 of incubation was determined to be linear; therefore, average daily growth rates were used for statistical analyses. The experimental design within each growth chamber was a randomized design blocked twice in time. Four replications of each isolate were included for each temperature treatment. Growth rates were analyzed as a randomized complete block design with multiple experimental units using SAS MIXED procedure, and means were separated using the Tukey least significant difference test $(P \leq 0.05)$.

Pseudothecia production. A mixture of tall fescue (Festuca arundinacea Schreb.) seed and wheat (Triticum aestivum L.) bran in equal volumes was evaluated as a culture medium for producing pseudothecia of $O$. agrostis. Tall fescue seeds were soaked in tap water overnight, rinsed three times, and mixed with wheat bran. The mixture was placed in 50-ml flasks and autoclaved for $1 \mathrm{~h}$ on two consecutive days. Mycelia from the edge of an actively growing colony of the single ascospore $O$. agrostis isolate OpMD-9 were transferred to the surface of the cooled seed/bran mix. Flasks then were incubated in a growth chamber under constant light $\left(88 \mu \mathrm{mol} \cdot \mathrm{m}^{-2} \cdot \mathrm{s}^{-1}\right.$ from four F20T12/CW, 20-W bulbs (Philips Lighting, Somerset, NJ) at $25^{\circ} \mathrm{C}$ for 16 to 18 days. Inoculum was mixed daily to promote aeration and to allow mycelium to become evenly distributed throughout the medium. Approximately $0.25 \mathrm{~g}$ of the infested mix then was placed on sterile, moist filter paper in a 60 by $15 \mathrm{~mm}$ petri dish. Petri dishes containing infested media were placed in one of three conditions as follows: (i) on a lab bench in ambient light (i.e., approximately $12 \mathrm{~h}$ of $4 \mu \mathrm{mol} \cdot \mathrm{m}^{-2} \cdot \mathrm{s}^{-1}$ fluorescent light); (ii) in a benchtop growth hood (Model \#11000, Labconco Corporation, Kansas City, MO) under constant light $\left(17 \mu \mathrm{mol} \cdot \mathrm{m}^{-2} \cdot \mathrm{s}^{-1}\right)$ supplied from a fluorescent, cool-white, 30-W bulb (F30T8/CW, General Electric, Fairfield, CT); or (iii) in a growth chamber (I30BLL, Percival Scientific, Inc., Perry, IA) at $25^{\circ} \mathrm{C}$ in constant light $\left(72 \mu \mathrm{mol} \cdot \mathrm{m}^{-2} \cdot \mathrm{s}^{-1}\right)$ from a fluorescent, cool-white, 20-W bulb (F20T12/CW, Philips Lighting). Temperatures on the lab bench ranged from 13 to $28^{\circ} \mathrm{C}$. Treatments also were subjected to constant dark by covering petri dishes with aluminum foil and placing them in the three aforementioned conditions. The filter paper was kept moist throughout the study to prevent the medium from drying. The medium was monitored daily for the appearance of pseudothecia.

In preliminary experiments, the number of pseudothecia produced on individual tall fescue seeds generally did not exceed 25 , but on occasion as many as 45 pseudothecia were counted on a single seed. Therefore, seeds were rated visually for abundance of pseudothecia on a 0 to 5 linear scale where $0=$ none, $3=11$ to 15 , and $5=$ $\geq 21$ pseudothecia with necks partially embedded in each tall fescue seed. The experiment was arranged as a $2 \times 3$ factorial with three replications. Data from treatments in which pseudothecia did not develop were excluded from statistical analyses. The study was repeated and data from each study were combined for the statistical analyses. For each rating date, pseudothecia ratings were analyzed using the SAS MIXED procedure, and means were separated based on Fisher's protected $(P \leq$ 0.05 ) least significant difference multiple mean comparison test. In addition, regression analyses were performed to determine the rate of pseudothecia production for each treatment, and regression lines were compared using the method described by Neter and Wasserman (11).

Ascospore germination. Ascospores were obtained from pseudothecia of isolate OpMD-9 produced in vitro. Approximately $0.25 \mathrm{~g}$ of the infested tall fescue/wheat bran mix was placed on moist filter paper in a petri dish and placed in a growth chamber at $25^{\circ} \mathrm{C}$ under constant light as previously described. Maximum numbers of pseudothecia were present approximately 1 month after incubation, and ascospores were determined to be mature when 
they were forcefully discharged from pseudothecia when observed under a stereomicroscope. An ascospore solution was prepared by wrapping the infested mix in cheesecloth and submerging it in $100 \mathrm{ml}$ of distilled water for $2 \mathrm{~min}$. Pseudothecia were not surface disinfested because mature ascospores would exude into the disinfectant. The concentration of ascospores discharging in water was determined with a Levy hemacytometer (VWR Scientific,
West Chester, PA), and dilutions were made to obtain approximately $7.5 \times 10^{2}$ ascospores $\mathrm{ml}^{-1}$. A 100- $\mu$ l aliquot of the suspension (about 75 ascospores) was placed on a microscope slide along with three 10-mm-long sections of creeping bentgrass leaves or roots or with no bentgrass tissue (distilled water control). Bentgrass leaves and roots were obtained from 3-month-old 'L-93' creeping bentgrass grown in a greenhouse. Leaf and root tis-

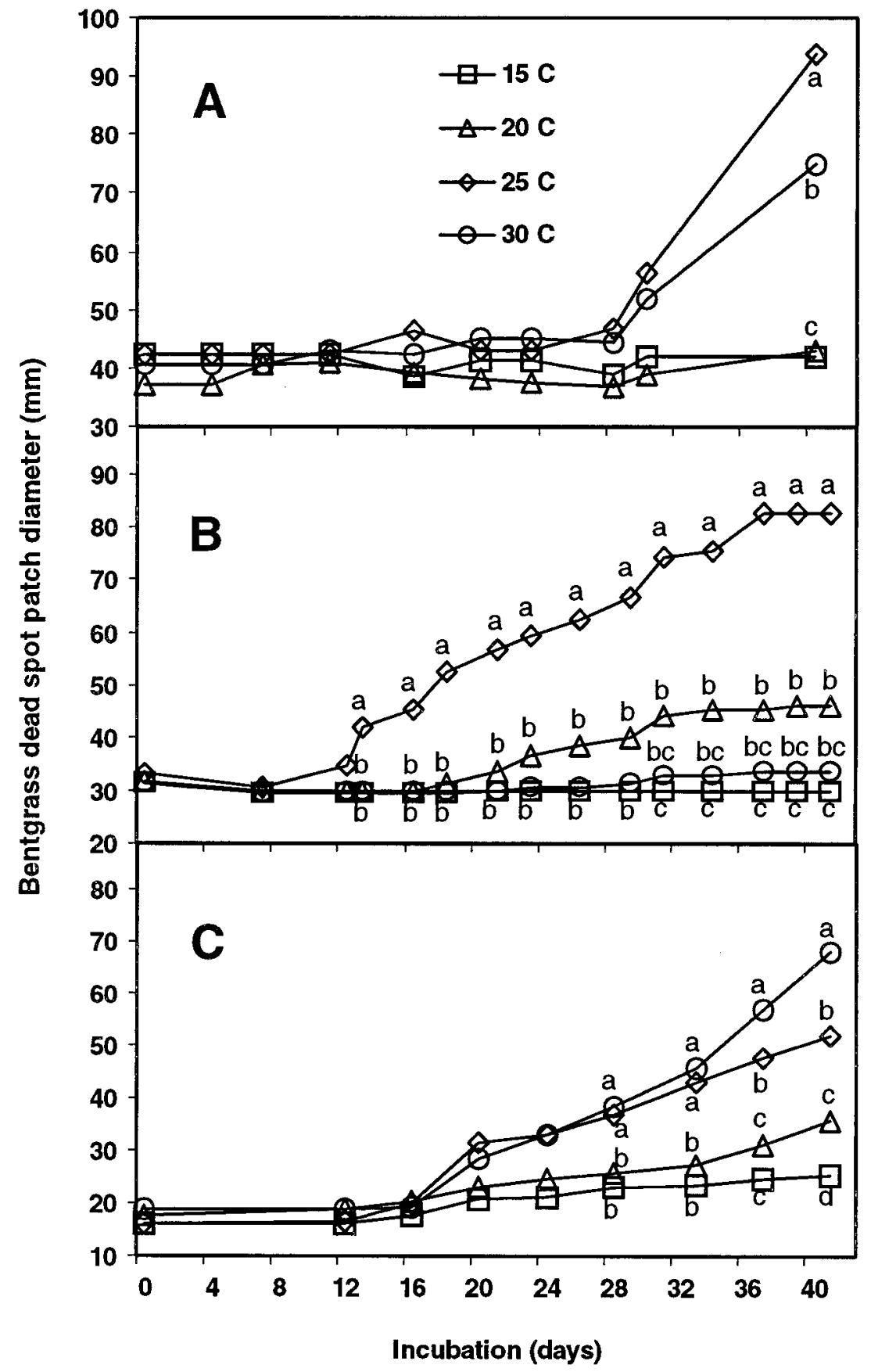

Fig. 1. Effect of temperature on the diameter of bentgrass dead spot patches from previously diseased creeping bentgrass over a 40- to 41-day period of incubation at four temperatures: A, Virginia plugs collected 1 February 1999; B, Pennsylvania plugs collected 28 February 2000; and C, Maryland plugs collected 17 January 2001. Letters are shown only where there are significant differences among treatments. For individual rating dates, points marked by the same letter are not significantly different according to Fisher's protected $(P \leq 0.05)$ least significant difference multiple mean comparison test. sue were washed in running tap water for 60 min prior to incubation with ascospores. Slides were placed inside two plastic humidity boxes lined with moistened paper towels and incubated at $25^{\circ} \mathrm{C}$ in either constant light $\left(88 \mu \mathrm{mol} \cdot \mathrm{m}^{-2} \cdot \mathrm{s}^{-1}\right)$ or constant darkness. For dark treatments, the humidity box was covered with aluminum foil. Distilled water was periodically added to each slide to prevent ascospore desiccation. Individual slides were removed from the incubator after 2, 4, 6, 8, 12, 18, and $24 \mathrm{~h}$ for observation. Ascospores were fixed and stained in lactophenol-cotton blue, and slides were sealed with Cytoseal 60 low viscosity mounting medium (Stephens Scientific, Kalamazoo, MI). Germinated spores were counted and percent germination was determined. For germinated ascospores, the number of germ tubes that developed and their location of origin within each ascospore were determined. The slides were completely randomized in each humidity box with three replicates. The study was repeated and percent germination data from each study were analyzed using the SAS MIXED procedure. Means were separated using Fisher's protected $(P$ $\leq 0.05$ ) least significant difference test.

\section{RESULTS AND DISCUSSION}

BDS reactivation. In plugs collected from Virginia, there was no visual evidence of reactivation of the disease within 28 days of incubation at any temperature. After 28 days, however, plugs incubated at 25 and $30^{\circ} \mathrm{C}$ began to exhibit reddishbrown leaves along the periphery of BDS spots, and the patch diameter began to increase (Fig. 1A). Plugs incubated at $25^{\circ} \mathrm{C}$ exhibited the most rapid increase in patch diameter. The Virginia site was overseeded prior to collecting plugs, and healthy creeping bentgrass seedlings emerged in the dead spots. Survival of the seedlings was not noted, as seedlings were removed as they germinated. O. agrostis was isolated from all four plugs maintained at 15 and $20^{\circ} \mathrm{C}$, but the pathogen was not isolated from plugs maintained at 25 or $30^{\circ} \mathrm{C}$.

Based on the development of a bronze or reddish-brown discoloration of leaves of plants adjacent to dead spots, reactivation of BDS in Pennsylvania plugs occurred 12 to 18 days after incubation began at 25 and $20^{\circ} \mathrm{C}$, respectively (Fig. 1B). Plugs incubated at $25^{\circ} \mathrm{C}$ exhibited the most rapid increase in patch diameter. BDS symptoms (foliar discoloration) developed at day 23 at $30^{\circ} \mathrm{C}$, but patch size did not increase appreciably through 40 days of incubation. Although no new disease symptoms were observed on healthy tissue in plugs maintained at $15^{\circ} \mathrm{C}, O$. agrostis was isolated from discolored or senescent leaves of plants maintained at all temperatures. No BDS symptoms developed on turf in the disease-free control plugs at any temperature.

Prior to initiation of the trial for the MD plugs, pseudothecia were found in the dead 
spots. After 5 days of incubation, mycelia were observed growing from exposed surfaces of pseudothecia in dead spots of plugs maintained at $25^{\circ} \mathrm{C}$. Twelve days after incubation began, $O$. agrostis was isolated from bronze or tan-colored bentgrass leaves from plugs incubated at 20, 25 , and $30^{\circ} \mathrm{C}$. Plugs incubated at $15^{\circ} \mathrm{C}$ exhibited no new disease symptoms, and the pathogen could not be recovered at this time. After 16 days of incubation, patch diameter of diseased plugs maintained at 25 and $30^{\circ} \mathrm{C}$ began to increase (Fig. 1C). By 41 days of incubation, plugs maintained at $30^{\circ} \mathrm{C}$ had the largest patch diameter. Patch diameter of plugs incubated at $20^{\circ} \mathrm{C}$ was larger than was observed in plugs incubated at $15^{\circ} \mathrm{C}$ on day 41. O. agrostis was isolated from bentgrass leaves located at the periphery of BDS patches from all plugs maintained at all temperatures on day 41. No symptoms developed on the disease-free control plugs at any temperature.

As was observed in the field (5), patch diameter generally did not exceed $80 \mathrm{~mm}$. The pathogen was isolated from senescent leaves of plants adjacent to diseased spots in plugs from all sites, indicating that $O$. agrostis is capable of surviving in winterdormant leaf tissue. Hyphae generally were not observed on the roots of $O$. agrostisinfected plants. Dark-brown to black hyphal masses and runner hyphae of $O$. agrostis, however, commonly were observed near or on the nodes of bentgrass stolons. Dark brown to black hyphae were observed less frequently on internodes and on roots emerging from the stem base of infected plants or the nodes of stolons.

Crahay et al. (3) reported that $O$. korrae may be capable of invading bermudagrass roots as soil temperatures decline and the host begins to enter winter dormancy. Although optimum temperature for growth of $O$. korrae on PDA is $25^{\circ} \mathrm{C}$, root growth of bermudagrass is stimulated at this temperature, and the pathogen was unable to cause significant injury at $25^{\circ} \mathrm{C}$ (3). Optimum temperatures for growth of creeping bentgrass shoots and roots are 16 to $24^{\circ} \mathrm{C}$ and 10 to $18^{\circ} \mathrm{C}$, respectively (1). Creeping bentgrass growing at 15 to $20^{\circ} \mathrm{C}$, therefore, may have a competitive growth advantage over $O$. agrostis at these temperatures. As noted below, $O$. agrostis grows on PDA at 15 to $20^{\circ} \mathrm{C}$; however, disease development generally was not observed on plugs at these temperatures. These observations indicate that temperatures favoring bentgrass growth render plants more resistant to infection. Reactivation of BDS may occur in as little as 12 or 16 days when incubated continuously at 25 or $30^{\circ} \mathrm{C}$, respectively. As shown below, 25 and $30^{\circ} \mathrm{C}$ were the optimum temperatures for growth of $O$. agrostis on PDA. Because the optimum temperature for root and shoot growth of cool-season grasses is $\leq 24^{\circ} \mathrm{C}$, the pathogen appears to have its greatest competitive advantage at temperatures between 25 and $30^{\circ} \mathrm{C}$. Observations from this study indicate that pseudothecia may germinate directly to produce mycelia. Hence, $O$. agrostis can survive winter in or on infected leaf tissue and stolons as well as overwintering pseudothecia.

Cardinal temperature for growth of o. agrostis. Analyses of growth rates for each isolate of $O$. agrostis revealed a significant temperature $\times$ isolate interaction $(P<0.005)$. Growth was very slow $(\leq 0.5$ $\left.\mathrm{mm} \mathrm{day}{ }^{-1}\right)$ in all isolates when incubated at $35^{\circ} \mathrm{C}$ (Fig. 2). When incubated at the lowest temperature $\left(10^{\circ} \mathrm{C}\right)$, the growth rate of all isolates ranged from 0.7 to $1.5 \mathrm{~mm}^{\text {day }}{ }^{-}$ 1. The growth rates of all isolates, however, increased with increasing temperature. The maximum growth rate for all isolates occurred between 25 and $30^{\circ} \mathrm{C}$ and ranged from 4.1 to $6.1 \mathrm{~mm} \mathrm{day}^{-1}$. At every temperature, OpMD-6 and OpMD-9 generally exhibited the fastest and slowest growth, respectively, among all isolates.

Colony morphology and color varied among temperatures and isolates. Colonies incubated at 10 to $25^{\circ} \mathrm{C}$ exhibited a fluffy, aerial growth, while mycelial growth at 30 and $35^{\circ} \mathrm{C}$ was considerably more condensed. At $25^{\circ} \mathrm{C}$, the isolates initially developed a rose-quartz color, with a buff outer edge. After 5 to 7 days of incubation, the center of colonies generally had a gray appearance at $25^{\circ} \mathrm{C}$. At $30^{\circ} \mathrm{C}$, colonies were dark pink to red and had a buff outer edge. Unlike the other isolates, OpOH-1 had a fluffy, white to olive-gray colored mycelium, which remained evident at the end of the 10-day incubation period at all temperatures in which growth occurred. In addition, the undersides of plates for $\mathrm{OpOH}-1$ were a dark brown to black color as opposed to beige or tan for the other isolates.

In summary, the optimum temperature for growth of all isolates was either 25 or $30^{\circ} \mathrm{C}$. Growth and morphology of $O$. agrostis, however, varied among isolates at each temperature. Very little or no growth occurred at temperatures as low as 10 or as high as $35^{\circ} \mathrm{C}$. The optimum temperatures for growth of $O$. agrostis in vitro (25 to $30^{\circ} \mathrm{C}$ ), however, exceeded temperatures that are favorable for shoot growth of coolseason grasses $\left(16\right.$ to $\left.24^{\circ} \mathrm{C}\right)(1)$. BDS generally appears in the field in the summer when daytime air temperatures exceed $25^{\circ} \mathrm{C}$. Hence, $O$. agrostis appears to have a competitive growth advantage over bentgrass in the summer.

Colony morphology and color, and the growth rate of $O$. agrostis on PDA, can be used to help distinguish this pathogen from other Ophiosphaerella spp. O. herpotricha grown on PDA produces a white, cottony mycelium that turns tan or brown within 3 to 7 days, and optimum growth occurs at

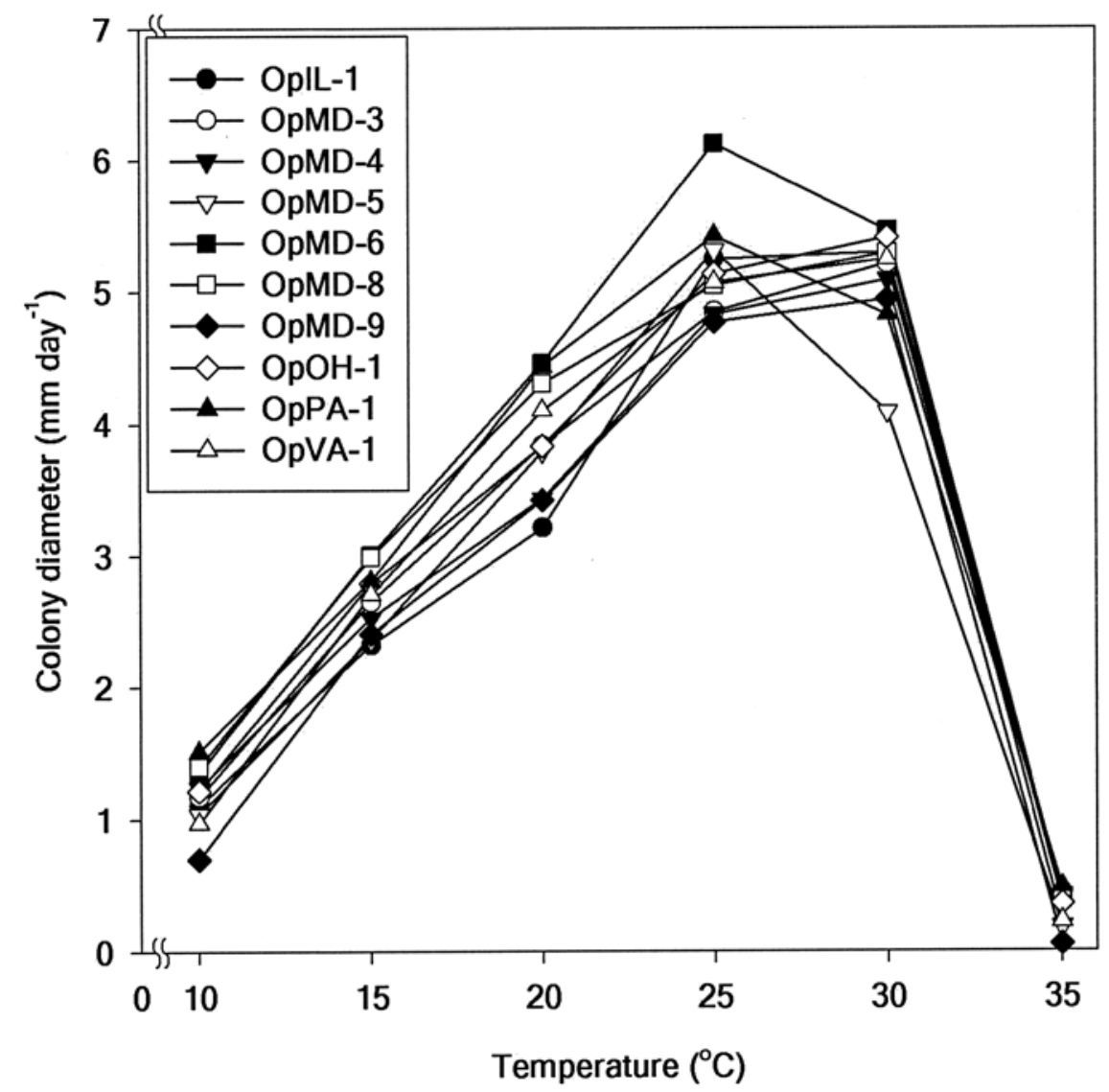

Fig. 2. Average daily growth of 10 Ophiosphaerella agrostis isolates incubated on potato dextrose agar at six temperatures for 10 days. 
20 to $25^{\circ} \mathrm{C}$ (16). O. herpotricha produces a brownish-black liquid on colonies, and $O$. korrae colonies have a distinctive domelike growth habit (18). On PDA, maximum colony growth for $O$. korrae and $O$. narmari occurs at $25^{\circ} \mathrm{C}$, and aerial mycelium of both species initially is white to buff and darkens as colonies age $(17,18)$. O herpotricha and $O$. korrae exhibit little or no growth when incubated at $30^{\circ} \mathrm{C}$ on PDA $(3,16)$. When incubated at $25^{\circ} \mathrm{C}, O$. agrostis generally can be differentiated from other Ophiosphaerella spp. by its rose-quartz colony color. The only exception was $\mathrm{OpOH}-1$, which produces an olive-gray colored mycelium. Differences in colony color associated with $\mathrm{OpOH}-1$, however, may add to the difficulties of properly distinguishing $O$. agrostis at $25^{\circ} \mathrm{C}$. However, O. agrostis can be distinguished from other Ophiosphaerella spp. by the generally dark pink to red, velvety mycelium and faster growth rate (i.e., average $=5.1 ;$ range $=4.1$ to $5.3 \mathrm{~mm} \mathrm{day}^{-1}$ ) when incubated at $30^{\circ} \mathrm{C}$.

Pseudothecia production. After 31 days incubation, no pseudothecia developed on the tall fescue/wheat bran mix subjected to constant dark or to diurnal ambient light. Pseudothecia, however, developed in the growth chamber and growth hood when exposed to constant light. The pseudothecia primarily were found partially embedded in the tall fescue seeds, but several pseudothecia formed directly on the paper (Fig. 3). Initial development of pseudothecia on 16- to 18-dayold media began in both treatments between 4 and 7 days after they were placed in constant light. There were no differences in the development of pseudothecia between samples placed in the growth chamber or growth hood on any individual rating date (data not shown). There also were no differences between regression lines for the growth chamber and growth hood data. Data from both treatments, therefore, were combined to determine the regression line: $P=0.181$ (DOI) $-0.030\left(R^{2}=0.88 ; P=\right.$ $0.0001)$, where $P=$ the pseudothecia rating on a 0 to 5 scale and DOI = days of incubation (Fig. 4).

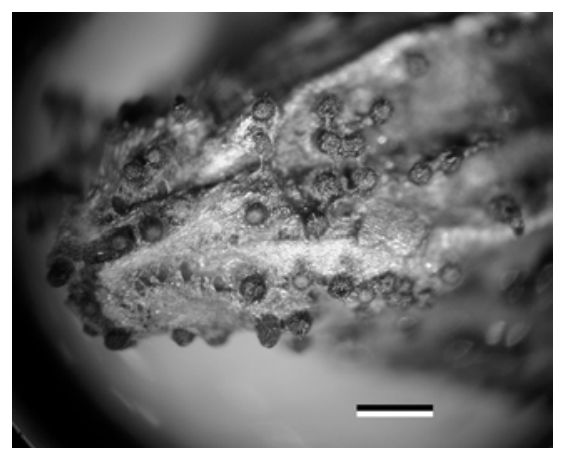

Fig. 3. Ophiosphaerella agrostis pseudothecia produced on a tall fescue seed after 30 days of incubation under constant light in a growth chamber $\left(25^{\circ} \mathrm{C}\right)$. Bar $=250 \mu \mathrm{m}$.
In summary, pseudothecia of $O$. agrostis readily were produced in vitro using the tall fescue seed/wheat bran mix, and maximum pseudothecia development occurred in about 30 days on moistened filter paper maintained under constant light, but they were not produced in darkness. Hammer and Chastagner (9) also found that $O$. korrae pseudothecia were not produced in the dark. Pseudothecia of $O$. agrostis developed in as few as 4 days, and ascospores had developed after 7 days incubation. Ascospore $(\mathrm{n}=100)$ length $($ mean $=$ $135 \mu \mathrm{m}$, range $=80$ to $175 \mu \mathrm{m}$ ) and the number of septations (mean $=13$, range $=$ 6 to 15$)$ generally were within the range reported by Câmara et al. (2) (data not shown). Several ascospores, however, were longer than the 150- $\mu \mathrm{m}$ length (range $=75$ to $150 \mu \mathrm{m}$ ) reported by Câmara et al. (2).

Large numbers of $O$. agrostis pseudothecia can be found in the field on dead tissue in the summer $(4,5)$. In an unrelated study, pseudothecia developed on tall fescue/wheat bran mix in ambient diurnal light in March and April, but not in December or January. Hence, longer day lengths in the field in the summer might be a key factor in pseudothecia production in vivo. Small numbers of pseudothecia of $O$. korrae, $O$. narmari, and $O$. herpotricha were produced in vitro on dead tissues of inoculated plants $(3,13,16,17,20)$. Crahay et al. (3) induced $O$. korrae pseudothecia by incubating infected bermudagrass roots for 6 weeks in moistened cheesecloth in test tubes. Mature $O$. korrae pseudothecia also were obtained by inoculating Scaldis hard fescue (Fescue longifolia Thuill.) seedlings that were grown on water agar (9). In all of the aforementioned studies, host tissues were used for the development of pseudothecia. Hence, another distin- guishing characteristic of $O$. agrostis is its ability to produce prodigious numbers of pseudothecia in vitro in a short period of time. Because $O$. agrostis pseudothecia developed both on a lab bench (temperature range $=13$ to $28^{\circ} \mathrm{C}$ ) and in a growth chamber $\left(25^{\circ} \mathrm{C}\right)$, temperature may be less important in ascocarp production than light and moisture. Although a single isolate was used in this study, we have observed that various $O$. agrostis isolates also produce pseudothecia in vitro.

Ascospore germination. Combined analyses of ascospore germination data revealed significant $(P \leq 0.05)$ differences between the two studies. Separate statistical analyses, therefore, were conducted on data from studies I and II (Table 1). In study $\mathrm{I}$, there was a significant $(P \leq 0.001)$ three-way interaction among light, tissue, and hours of incubation. Germination of ascospores in all treatments, except the control (i.e., distilled water) incubated in the dark, had begun after $2 \mathrm{~h}$ (Fig. 5). After $4 \mathrm{~h}$ of incubation, significant differences in ascospore germination among light treatments were apparent. Ascospores incubated under constant light with either leaf or root tissue exhibited the greatest germination (34 to $35 \%$ ). In the dark, the same tissue treatments exhibited significantly less ascospore germination (18 to $21 \%$ ) at $4 \mathrm{~h}$. Control treatments incubated in either light or dark resulted in the lowest percent germination (6 to 7\%) after $4 \mathrm{~h}$. Ascospore germination in both light and dark controls, however, increased significantly after $6 \mathrm{~h}$ of incubation. Similar levels of germination occurred among leaf and root treatments incubated for $6 \mathrm{~h}$ in constant dark and in the control in constant light. Although the greatest percentage of germinating ascospores occurred when ascospores

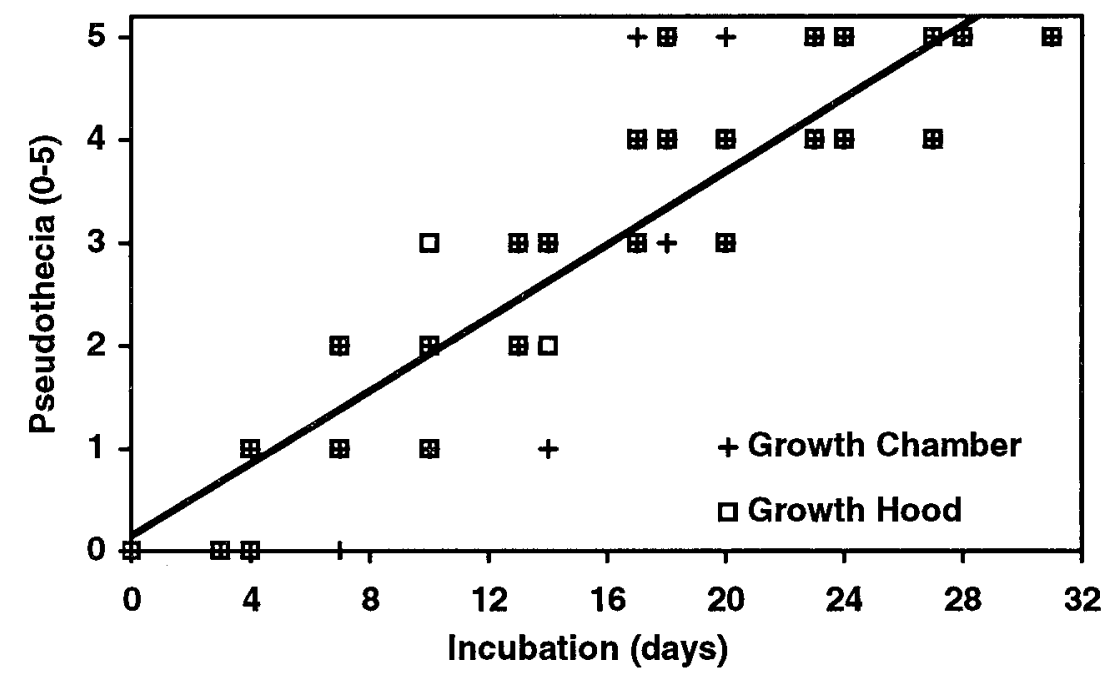

Fig. 4. In vitro development of Ophiosphaerella agrostis pseudothecia on tall fescue/wheat bran media over 31 days of incubation (DOI) under constant light in a growth hood $\left(13\right.$ to $\left.28^{\circ} \mathrm{C}\right)$ or in a growth chamber $\left(25^{\circ} \mathrm{C}\right)$. Pseudothecia development $(P)$ was rated visually on a 0 to 5 linear scale where $0=$ no pseudothecia present, $3=11$ to 15 pseudothecia per tall fescue seed, and $5=\geq 21$ pseudothecia per tall fescue seed. The equation of the regression line for pseudothecia development, combined for both treatments and studies, was $P=0.181(\mathrm{DOI})+0.030\left(R^{2}=0.88 ; P=0.0001\right)$. 
were incubated for $6 \mathrm{~h}$ with leaves or roots in the presence of light, there were no significant differences among the aforementioned treatments and the root or control treatments incubated in darkness. With few exceptions, ascospore germination increased in all treatments from 6 to $8 \mathrm{~h}$ of incubation. Ascospores in the control treatment incubated in the dark for $8 \mathrm{~h}$, however, exhibited the least germination (35\%), which was similar to the percentages observed after $6 \mathrm{~h}(31 \%)$. After $8 \mathrm{~h}$, the greatest number of germinated ascospores (76 to $79 \%$ ) occurred in the leaf and control treatments incubated in light; whereas, fewer ascospores had germinated (57 to 63\%) when incubated in the dark with either bentgrass leaves or roots. The percentage of ascospores germinating for all treatments incubated in light did not increase significantly after $8 \mathrm{~h}$. All dark treatments continued to exhibit increases in ascospore germination until $18 \mathrm{~h}$, after which time there was little increase in germination. Few significant differences in ascospore germination occurred among treatments after $24 \mathrm{~h}$ of incubation, and all treatments exhibited 71 to $85 \%$ germination at this time.

In study II, the highest level of interaction $(P \leq 0.05)$ was the two-way interaction of light $\times$ hours of incubation (Table 1). No treatment interactions involving tissue were found; however, the main effect of tissue was significant $(P \leq 0.001)$. Ascospore germination data for light and hours of incubation, therefore, were combined for leaves, roots, and the control for each light $\times$ hour interaction. Because the main effect of tissue was not included in any significant interactions, tissue data also were combined for both light and dark treatments for all hours of incubation.

The greatest percent germination was observed when ascospores were incubated in the presence of leaves versus roots versus the control (Fig. 6). The magnitude of the difference, however, was small (3 to $7 \%$ germination). Similar to the results in study I, ascospore germination was observed after $2 \mathrm{~h}$ of incubation (Fig. 7). At $2,6,8$, and $12 \mathrm{~h}$ of incubation, more ascospores germinated in light $(12,31,48$, and $57 \%$, respectively) when compared to those incubated in the dark $(3,18,39$, and $49 \%$, respectively). Although there were no differences between light and dark treatments after 4 , 18, or $24 \mathrm{~h}$, ascospore germination continued to increase, and after $24 \mathrm{~h}$ of incubation nearly all ascospores had germinated.

In summary, ascospore germination can occur in as little as $2 \mathrm{~h}$, and a large percentage of ascospores had germinated after $8 \mathrm{~h}$ of incubation. During the early hours of incubation, ascospores generally germinated in larger numbers in the presence of light and bentgrass leaves or roots. Ascospores incubated with bentgrass leaves generally exhibited similar or greater levels of germination when compared to ascospores incubated with roots. Ascospores incubated with either tissue type for 2 to 12 $\mathrm{h}$, however, generally resulted in a greater percent germination when compared to ascospores incubated in water alone. After $18 \mathrm{~h}$ of incubation, however, there were few percent germination differences among treatments.

On average, $\leq 2$ germ tubes per ascospore developed within the first $6 \mathrm{~h}$ of incubation (data not shown). The maximum number of germ tubes that developed from an individual ascospore was four, and ascospores with $\geq 3$ germ tubes accounted for an average of 6 and $11 \%$ of the total percentage of germinated ascospores in studies I and II, respectively. Germination generally occurred at the terminal cells of ascospores, and an average of 73 and $58 \%$ of the total percentage of germinating ascospores between 2 and $6 \mathrm{~h}$ of incubation occurred at one or both ends of ascospores in studies I and II, respectively. Germina-

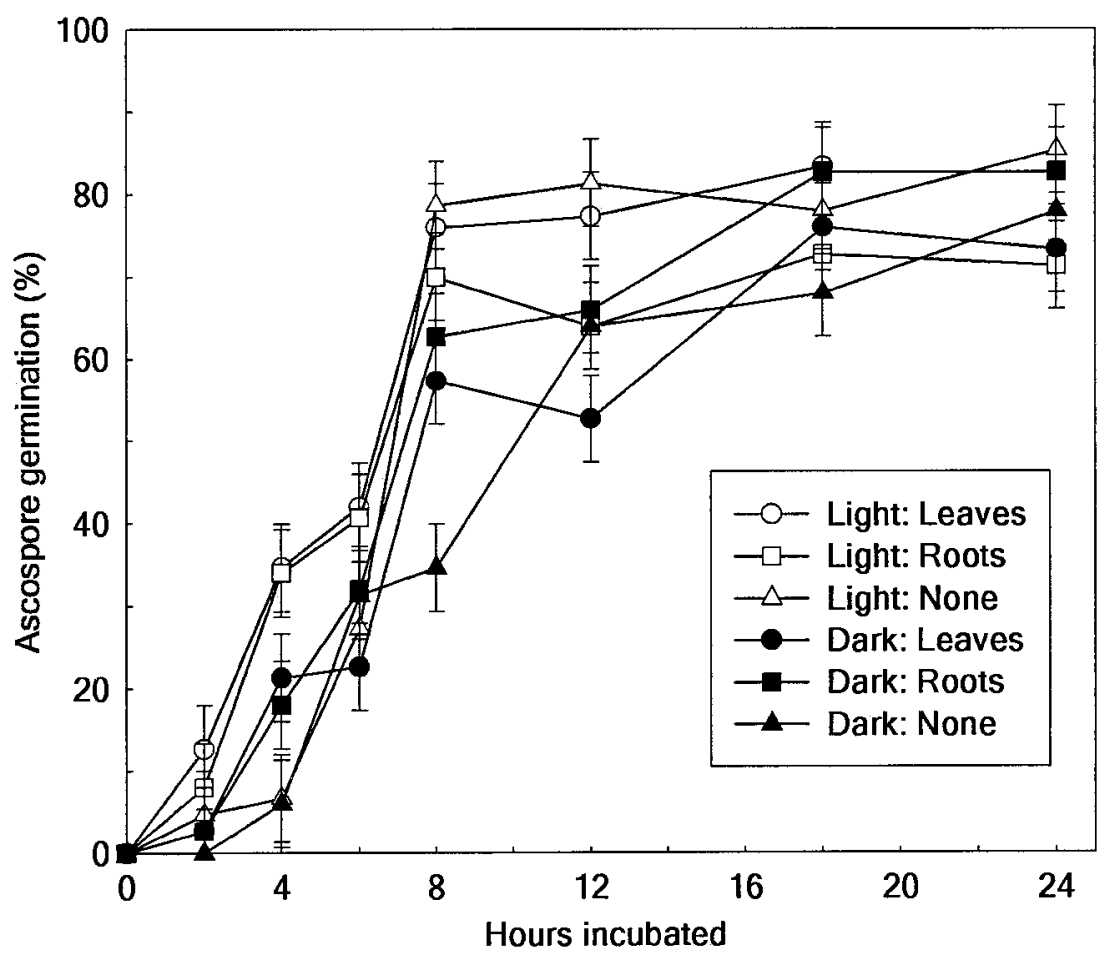

Fig. 5. Percent germination of Ophiosphaerella agrostis ascospores in study I incubated at various time intervals at $25^{\circ} \mathrm{C}$ with or without 'L-93' creeping bentgrass leaves or roots in either constant light or darkness. Error bars indicate significant differences $(P \leq 0.05)$ among tissue treatments and hours incubated. Germination data collected from 50 ascospores in each of three replications $(\mathrm{n}=150)$.

Table 1. Analysis of variance for Ophiosphaerella agrostis ascospore germination data after incubation at various time intervals at $25^{\circ} \mathrm{C}$ with or without 'L-93' creeping bentgrass leaves or roots in either constant light or darkness

\begin{tabular}{|c|c|c|c|c|c|c|c|c|}
\hline \multirow[b]{2}{*}{ Source of variance } & \multicolumn{4}{|c|}{ Study I } & \multicolumn{4}{|c|}{ Study II } \\
\hline & ndf $^{x}$ & ddf $^{y}$ & $F$ value & $P>F$ & ndf & ddf & $F$ value & $P>F$ \\
\hline Hours incubated (hours) & 6 & 84 & 334.6 & $* * * \mathrm{z}$ & 6 & 84 & 533.3 & $* * *$ \\
\hline Tissue type (tissue) & 2 & 84 & 5.9 & $* *$ & 2 & 84 & 14.7 & $* * *$ \\
\hline Light & 1 & 84 & 53.7 & $* * *$ & 1 & 84 & 28.4 & $* * *$ \\
\hline Hours $\times$ tissue & 12 & 84 & 4.4 & $* * *$ & 12 & 84 & 1.6 & NS \\
\hline Hours $\times$ light & 6 & 84 & 6.4 & $* * *$ & 6 & 84 & 3.2 & $* *$ \\
\hline Tissue $\times$ light & 2 & 84 & 8.2 & $* * *$ & 2 & 84 & 1.2 & NS \\
\hline Hours $\times$ tissue $\times$ light & 12 & 84 & 3.8 & $* * *$ & 12 & 84 & 0.8 & NS \\
\hline
\end{tabular}

${ }^{\mathrm{x}}$ Numerator degrees of freedom.

y Denominator degrees of freedom.

${ }^{\mathrm{z}} \mathrm{NS}=$ not significant; $* *, * * *=$ significant at $P \leq 0.01$ and 0.001 , respectively. 


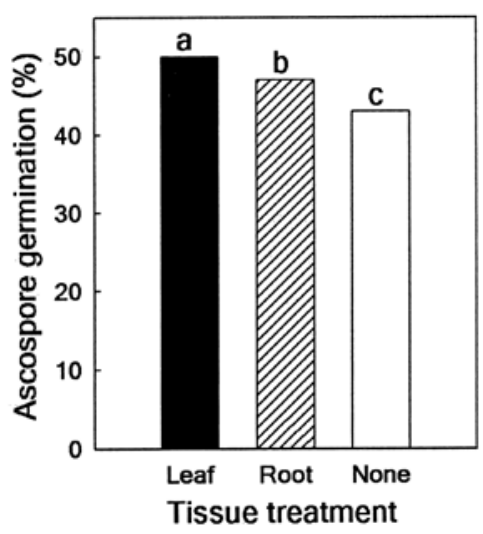

Fig. 6. Effect of creeping bentgrass tissue (leaf, root, and none) on Ophiosphaerella agrostis ascospore germination in study II incubated at $25^{\circ} \mathrm{C}$ over a 24-h period. Data were collected from 50 ascospores in each of three replications and were averaged over light and dark treatments. Bars labeled by different letters indicate significant differences in percent germination according to Fisher's protected $(P \leq 0.05)$ least significant difference multiple mean comparison test.

tion from the interior cells of ascospores occurred on a limited basis.

Sugars, amino acids, and other organic compounds are exuded by leaves and roots (1). Exudates from bentgrass leaves and roots, therefore, likely encouraged the germination of $O$. agrostis ascospores. Endo and Amacher (7) found that creeping bentgrass leaf exudates increased the rate and percentage of conidia germination in Bipolaris sorokiniana (Sacc.) Shoemaker (formerly Helminthosporium sorokinianum Sacc.). An increase in the incidence of brown patch (Rhizoctonia solani Kühn) also has been attributed to the presence of exudates on the surfaces of bentgrass leaves (12). In addition to exudates, extended leaf wetness duration caused by dew also provides a suitable environment for ascospore germination and germ tube development.

Ascospores of $O$. agrostis were ejected through ostioles of pseudothecia in light. In the presence of water, ascospores also exuded en masse from ostioles. Hence, ascospores can be dispersed by both water and wind. In the mid-Atlantic region, dew and leaf surface exudates develop in a bentgrass canopy at about $2000 \mathrm{~h}$ in the

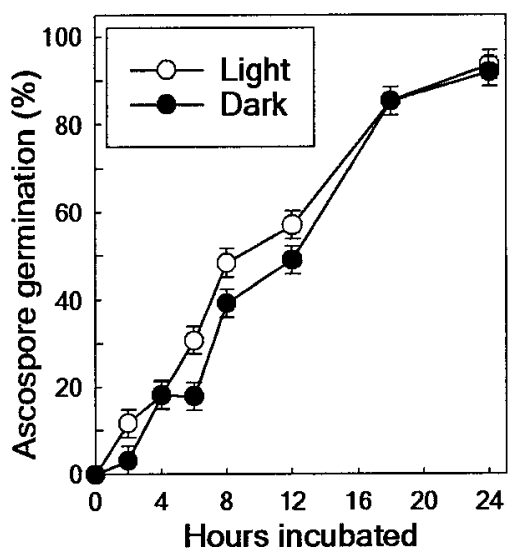

Fig. 7. Effect of light versus dark treatments on the germination of Ophiosphaerella agrostis ascospores in study II incubated at $25^{\circ} \mathrm{C}$ over a 24-h period. Error bars indicate significant differences $(P \leq 0.05)$ among light treatments and hours incubated.

summer, and leaves often remain wet until $1000 \mathrm{~h}$ when daytime temperatures reach $\geq 25^{\circ} \mathrm{C}$. Results indicated that ascospores alighting on wet leaves in the morning can begin germinating in $2 \mathrm{~h}$. In unrelated studies, germ tubes of ascospores were observed entering open stomates on bentgrass leaves. Appressorium formation and the subsequent direct penetration of the epidermal cells of creeping bentgrass leaves and roots by ascospores also were observed. Hence, leaf surface exudates appear to be an important factor in rapid germination and subsequent infection of leaves by $O$. agrostis during the morning hours.

\section{ACKNOWLEDGMENTS}

We are grateful for the financial support provided for this study by the United States Golf Association, and for helpful comments from Marcos Câmara, Arvydas Grybauskas, and Thomas Turner.

\section{LITERATURE CITED}

1. Beard, J. M. 1973. Turfgrass: Science and Culture. Prentice-Hall, Inc., Englewood Cliffs, NJ.

2. Câmara, M. P. S., O'Neill, N. R., van Berkum, P., Dernoeden, P. H., and Palm, M. E. 2000. Ophiosphaerella agrostis sp. nov. and its relationship to other species of Ophiosphaerella. Mycologia 92:317-325.

3. Crahay, J. N., Dernoeden, P. H., and O'Neill, N. R. 1988. Growth and pathogenicity of Leptosphaeria korrae in bermudagrass. Plant Dis.
72:945-949.

4. Dernoeden, P. H. 2000. Creeping Bentgrass Management: Summer Stress, Weeds, and Selected Maladies. Ann Arbor Press, Chelsea, MI

5. Dernoeden, P. H., O'Neill, N. R., Câmara, M. P. S., and Feng, Y. 1999. A new disease of Agrostis palustris incited by an undescribed species of Ophiosphaerella. Plant Dis. 83:397.

6. Dernoeden, P. H., Zhang, M., and Wetzel, H. C. 1995. First report of necrotic ring spot (Leptosphaeria korrae) in creeping red fescue in Maryland. Plant Dis. 79:966.

7. Endo, R. M., and Amacher, R. H. 1964. Influence of guttation fluid on infection structures of Helminthosporium sorokinianum. Phytopathology 54:1327-1334.

8. Endo, R. M., Ohr, H. D., and Krausman, E. M. 1985. Leptosphaeria korrae, a cause of the spring dead spot disease of bermudagrass in California. Plant Dis. 69:235-237.

9. Hammer, W., and Chastagner, G. 1987. Factors affecting the production of pseudothecia of Leptosphaeria korrae in vitro. (Abstr.) Phytopathology 77:1239.

10. Landschoot, P. J. 1996. First report of necrotic ring spot on Poа апnиа putting greens in Pennsylvania. Plant Dis. 80:712.

11. Neter, J., and Wasserman, W. 1974. Applied Linear Statistical Models. Richard D. Irwin, Inc., Homewood, IL.

12. Rowell, J. B. 1951. Observations on the pathogenicity of Rhizoctonia solani on bentgrass. Plant Dis. Rep. 35:240-242.

13. Smith, A. M. 1965. Ophiobolus herpotrichus a cause of spring dead spot in couch turf. Agric. Gazette N.S.W. 76:753-758.

14. Spegazzini, C. 1909. Mycetes Argentinenses, Ser VI. Annales Museo Nacional de Buenos Aires 19 (Ser. 3, 12):257-458.

15. Tisserat, N., Wetzel, H., III, Fry, J., and Martin, D. L. 1999. Spring dead spot of buffalograss caused by Ophiosphaerella herpotricha in Kansas and Oklahoma. Plant Dis. 83:199.

16. Tisserat, N. A., Pair, J. C., and Nus, A. 1989. Ophiosphaerella herpotricha, a cause of spring dead spot of bermudagrass in Kansas. Plant Dis. 73:933-937.

17. Walker, J., and Smith, A. M. 1972. Leptosphaeria narmari and $L$. korrae spp. nov. two long-spored pathogens of grasses in Australia. Trans. Br. Mycol. Soc. 58:459-466.

18. Wetzel, H. C., III, Dernoeden, P. H., and Millner, P. D. 1996. Identification of darkly pigmented fungi associated with turfgrass roots by mycelial characteristics and RAPDPCR. Plant Dis. 80:359-364.

19. Wetzel, H. C., Hulbert, S. H., and Tisserat, N. A. 1999. Molecular evidence for the presence of Ophiosphaerella narmari n. comb., a cause of spring dead spot of Bermuda grass, in North America. Mycol. Res. 103:581-589.

20. Worf, G. L., Stewart, J. S., and Avenius, R. C. 1986. Necrotic ring spot disease of turfgrass in Wisconsin. Plant Dis. 70:453-458. 